\title{
Himalayan ice-core dating with snow algae
}

\author{
Yoshitaka Yoshimura, ${ }^{1}$ Shiro Kohshima, ${ }^{2}$ Nozomu Takeughi, ${ }^{2}$ Katsumoto Seko, ${ }^{3}$ Koji Fujita ${ }^{3}$ \\ ${ }^{1}$ Mitsubishi Kasei Institute of Life Sciences, 11 Minamiooya, Machida-shi, Tokyo 194-8511, Japan \\ ${ }^{2}$ Basic Biology, Faculty of Bioscience and Biotechnology (c/o Faculty of Science), Tokyo Institute of Technology, \\ O-okayama 2-12-1, Meguro-ku, Tokyo 152-8551, Japan \\ ${ }^{3}$ Institute for Hydrospheric-Atmospheric Sciences, Nagoya University, Nagoya 464-8601, Japan
}

\begin{abstract}
Snow algae in shallow ice cores $(7 \mathrm{~m}$ long) from Yala Glacier in the Langtang region of Nepal were examined for potential use in ice-core dating. Ice-core samples taken at $5350 \mathrm{~m}$ a.s.l. in 1994 contained more than seven species of snow algae. In a vertical profile of the algal biomass, 11 distinct algal layers were observed. Seasonal observation in 1996 at the coring site indicated most algal growth occurred from late spring to late summer. Pit observation in 1991, 1992 and 1994 indicated that algal layer formation takes place annually. $\delta^{18} \mathrm{O}$, chemical ions $\left(\mathrm{Na}^{+}, \mathrm{Cl}^{-}, \mathrm{SO}_{4}{ }^{2-}\right.$ and $\left.\mathrm{NO}_{3}{ }^{-}\right)$and microparticles failed to show any clear seasonal variation, particularly at depths exceeding $2 \mathrm{~m}$, possibly due to heavy meltwater percolation. Snow algae in ice cores would thus appear to be accurate boundary markers of annual layers and should prove useful for ice-core dating in Himalayan-type glaciers.
\end{abstract}

\section{INTRODUCTION}

Ice cores contain various organic material. Airborne biotic particles such as pollens and fragments of plant tissue have been studied (Fredskild and Wagner, 1974; McAndrews, 1984; Koerner and others, 1988; Bourgeois, 1990), but only recently has the micro-organisms content of cores come to be studied (Abyzov and others, 1995; Karl and others, 1999; Priscu and others, 1999; Willerslev and others, 1999), although many micro-organisms, such as snow algae and bacteria, have been found on various glaciers in the world (Kol, 1942; Gerdel and Drouet, 1958; Kol and Flint, 1968; Kol, 1969; Kol and Peterson, 1976; Wharton and others, 1981; Kohshima, 1984a, b, 1987b, 1989; Ling and Seppelt, 1993; Yoshimura and others, 1997). On Yala Glacier in the Langtang region of Nepal, Kohshima (1984a, b, 1987a, b) found a specialized animal community comprised of cold-tolerant insects and copepods whose food source was algae and bacteria present in the snow and ice. These micro-organisms were observed to be present in glacial strata every year, and ice cores recovered from this glacier contained many layers each possessing these micro-organisms. Yoshimura and others (1997) observed that the biomass and community structure of snow algae clearly change with altitude, reflecting change in environmental conditions, and suggested snow algae may be useful for analyzing ice cores from Himalayan glaciers.

The authors considered that ice cores could best be studied by examining the following:

(1) Seasonal variation in algal growth: markers of annual layers for ice-core dating.

(2) Annual variation in algal biomass: markers from the glacier environment that affect algal production.

(3) Annual variation in algal community structure: markers from the glacier environment that determine interactions among algal species.
Since algal growth occurs only in the thawing season, layers with high algal content (algal layers) should serve as annual boundary markers in ice-core dating. The possibility of snow algae as a source of environmental markers (aspects 2 and 3) will be examined in a future paper.

An examination was carried out of snow algae in shallow ice cores $(7 \mathrm{~m}$ long) from Yala Glacier, together with $\delta^{18} \mathrm{O}$, chemical ions and microparticles, and the formation of algal layers, by monitoring of the seasonal variation in algal biomass at coring sites. Snow algae in ice cores were found to be quite useful as boundary markers of annual layers in a Himalayan glacier.

\section{METHODS}

\section{Site features}

Yala Glacier $\left(28^{\circ} 14-15^{\prime} \mathrm{N}, 85^{\circ} 36-38^{\prime} \mathrm{E}\right.$; $5100-5700 \mathrm{~m}$ a.s.l. situated in the southern Himalayan mountain range (Fig. la), is a plateau-shaped small glacier ( $4 \mathrm{~km}$ long) with no rock-debris cover. The late-summer snowline of the glacier (10-27 August 1991) was found to be $5250 \mathrm{~m}$ a.s.l. by stake measurement (Yoshimura and others, 1997). Ice coring and all snow-pit work were conducted at site A (5350 m a.s.l.) located on a flat snowfield (Fig. 1b).

\section{Sampling}

Ice cores (6.98 $\mathrm{m}$ long) were taken with a hand auger at site A (Fig. 1b) on 31 July 1994. Each core was immediately cut and bagged on site. To eliminate contamination, $1 \mathrm{~cm}$ of the core surface was scraped off with a clean knife before packaging. Sample vertical length was $3-14 \mathrm{~cm}$.

At site A, snow-pit studies were carried out on 31 July 1994 (a 2 m pit), 14 August 1992 (a 1.2 m pit) and 17 August 1991 (a $1 \mathrm{~m}$ pit). Following stratigraphic observation, samples were collected from the pit walls with a stainless-steel scoop and placed in pre-cleaned plastic bags. 


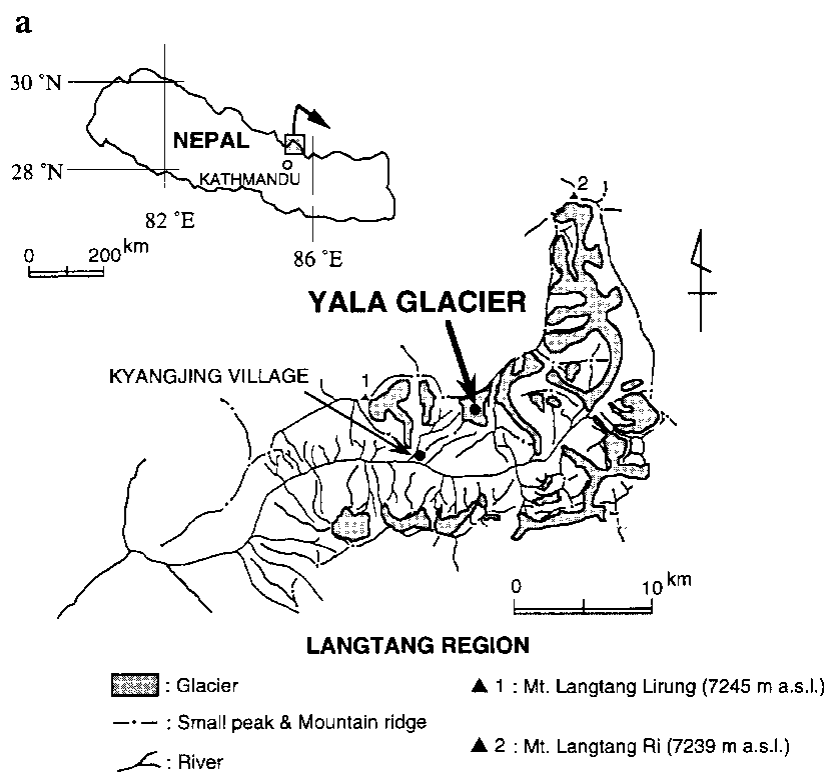

b

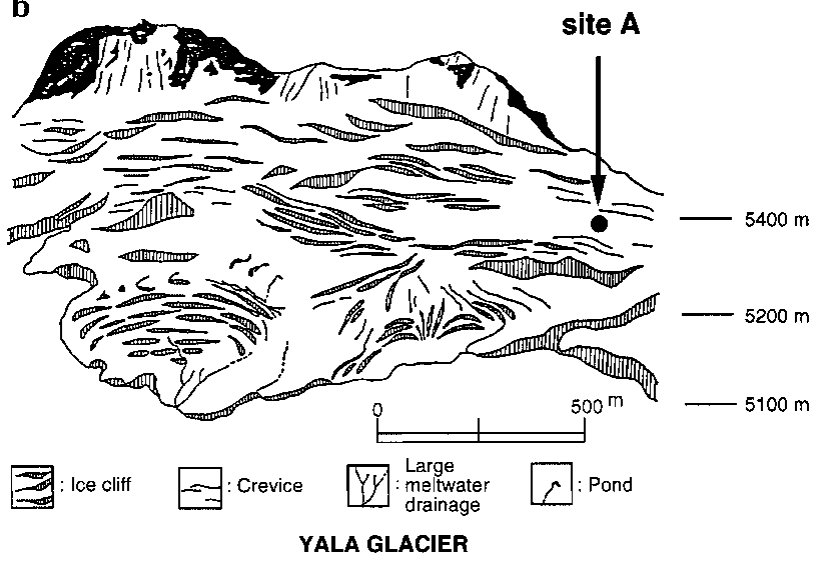

Fig. 1. (a) Location of Yala Glacier in Langtang region, Nepal, and (b) sampling point on Yala Glacier ( site A; 5350 m a.s.l.).

To examine seasonal changes in snow algae, near-surface snow was collected at site A on 20 May, 23 June, 28 July, 23 August and 3 October 1996. Algae had previously been found mainly in the uppermost dirty layer, so it was from this layer that the samples were taken. On each sampling day, four samples were taken from different places near site A.

All samples were melted at room temperature, kept in precleaned polyethylene bottles, fixed in 3\% formalin solution and, in this state, shipped to Japan. Samples for physical and chemical analysis were not fixed, but frozen $\left(-20^{\circ} \mathrm{C}\right)$ following arrival in Japan.

\section{Analysis}

Algal biomass in each sample was expressed as total algal volume $\left(\mu \mathrm{m}^{3} \mathrm{~mL}^{-1}\right)$. Cell count and volume determination were made with a microscope (NIKON OPTIPHOT 2). Before microscopic observation, sample staining was conducted with $0.5 \%$ erythrosin $(0.5 \mathrm{~mL}$ added to $1 \mathrm{~mL}$ sample) followed by ultrasound treatment to loosen sedimented particles. Two microliters of processed sample water were mounted on a glass slide under a cover-slip $\left(8 \times 8 \mathrm{~mm}^{2}\right)$ to count the algae. Ice-core samples in 1994 were filtered through Millipore filters (JHWP01300), and 0.5\% erythro$\sin (0.5 \mathrm{~mL})$ was introduced into the filter holder for staining. The filters were rinsed with filter-sterilized distilled water after 20 min and mounted on glass slides to count the algae.
The algal species were then classified. Unidentified cells were divided into six groups according to size $(5-6,7-8,9-$ $10,11-12,13-15,16-20 \mu \mathrm{m}$ in diameter). Algal density was expressed as "cells $\mathrm{mL}^{-1}$ " and cell volume $\left(\mu \mathrm{m}^{3}\right)$ was estimated based on size. Total algal biomass was determined by multiplying cell volume $\left(\mu \mathrm{m}^{3}\right)$ by algal density $\left(\right.$ cells $\left.\mathrm{mL}^{-1}\right)$.

Oxygen isotopes were examined by a MAT250 (Finnigan Mat Instruments Inc.) at Nagoya University. Microparticle concentrations $(5-20 \mu \mathrm{m}$ in diameter) and major-ion concentrations $\left(\mathrm{Na}^{+}, \mathrm{Cl}^{-}, \mathrm{SO}_{4}{ }^{2-}\right.$ and $\left.\mathrm{NO}_{3}{ }^{-}\right)$were determined with a Met One L-9000 (Transtech Inc.) and Dionex 2000i/sp ion chromatograph, respectively, at the National Institute of Polar Research, Tokyo.

\section{RESULTS AND DISGUSSION}

\section{Snow algae in ice cores}

The following seven algal species and one unidentified alga were examined in ice-core samples. The algae are described in detail in our previous paper (Yoshimura and others, 1997).

\section{Trochisciasp.}

Cells spherical with thick cell wall $(1-1.5 \mu \mathrm{m})$ ornamented by fine granules arranged at $0.8 \mu \mathrm{m}$ intervals. Cells $10-$ $20 \mu \mathrm{m}$ in diameter.

\section{Chloromonas sp.}

Biflagellate vegetative cells elliptic to cylindric with rounded apices. Cells $14-24 \mu \mathrm{m}$ in diameter, 20-28 $\mu \mathrm{m}$ long.

\section{Mesotaenium berggrenii}

Cells cylindric with rounded apices, $1-2$ times longer than the width, 5-10 $\mu \mathrm{m}$ wide, $8-20 \mu \mathrm{m}$ long.

\section{Cylindrocystis brebissonii}

Cells cylindric with rounded apices, 1-2 times longer than the width, $14-18 \mu \mathrm{m}$ wide, $22-32 \mu \mathrm{m}$ long.

\section{Ancylonema noldenskioeldii}

Filaments straight or slightly curved, consisting of 2-4-8 cells. Cells cylindric with truncate or rounded apices, 2-2.5 times longer than wide, $7-15 \mu \mathrm{m}$ wide, $15-30 \mu \mathrm{m}$ long.

\section{Raphidonema sp.}

Filaments straight or slightly curved, consisting of 2-4 cells. Cells cylindric with parallel margins, terminal cells gradually attenuated to the apices, $2-4 \mu \mathrm{m}$ wide, $12-25 \mu \mathrm{m}$ long.

\section{Oscillatoriacean algae}

Trichomes $1.5 \mu \mathrm{m}$ wide, 1.5 or $3.0 \mu \mathrm{m}$ long.

\section{Unidentified coccoid algae}

Cells spherical, 5-20 $\mu \mathrm{m}$ in diameter.

Yoshimura and others (1997) obtained 11 species of snow algae from Yala Glacier in 1991, and according to the particular height situated on the glacier they were classified as "upper and middle area","lower and middle area","middle area" and "all areas group". In any one core, most of the identified algae were of the "upper and middle area" or "all areas group", comprised of Raphidonema sp. and Mesotaenium berggrenii, respectively. In the deeper part of the ice core (deeper than $5 \mathrm{~m}$ ), algal structures were difficult to identify and species identification was particularly difficult, possibly owing to autolysis or bacterial decomposition of algae. In the deeper 
part of the core, Mesotaenium berggrenii and Oscillatoriacean algae appeared well preserved, compared to other algae.

\section{Results}

Vertical profiles of algal biomass (Fig. 2b) show 11 distinct peaks. The layers must surely have formed near the surface during melting seasons, considering that light and meltwater are required for algal growth.

\section{Formation of algal layers}

Algal biomass increased most rapidly at or near the snow surface, before there was snow covering the uppermost dirty layers of the pack, or when this overlying snow was thinnest and the amount of meltwater and light supplied to the algae was highest. Figure 3 shows this seasonal change in the algal biomass at site A (the coring site in 1994) for 1996. Algal growth started at the beginning of June and con-

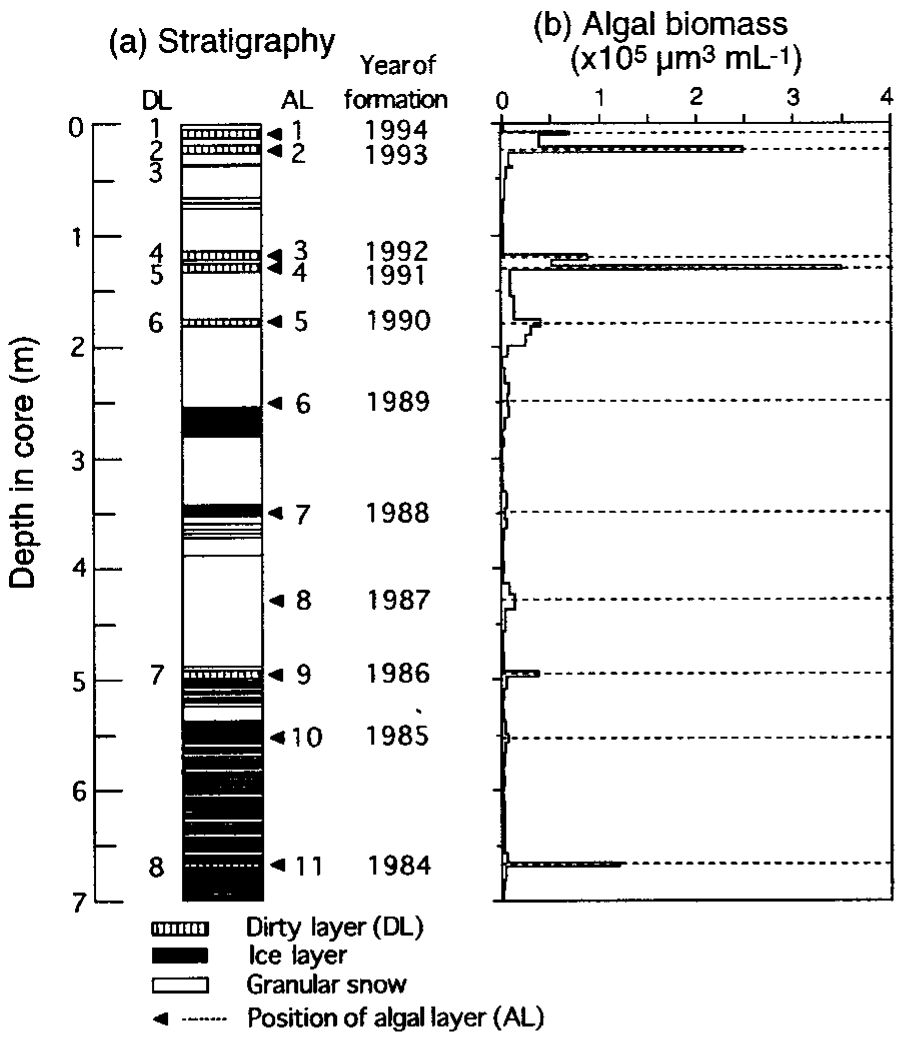

(c) Particles $(5-20 \mu \mathrm{m})$ $\left(\times 10^{2} \mathrm{~mL}^{-1}\right)$

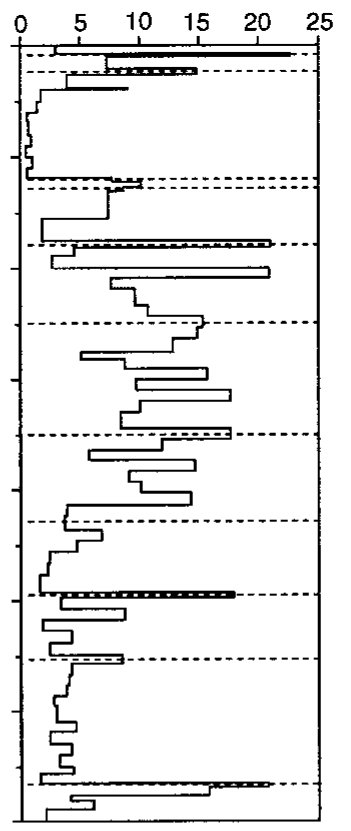

(d) Delta ${ }^{18} \mathrm{O}$ (permil)

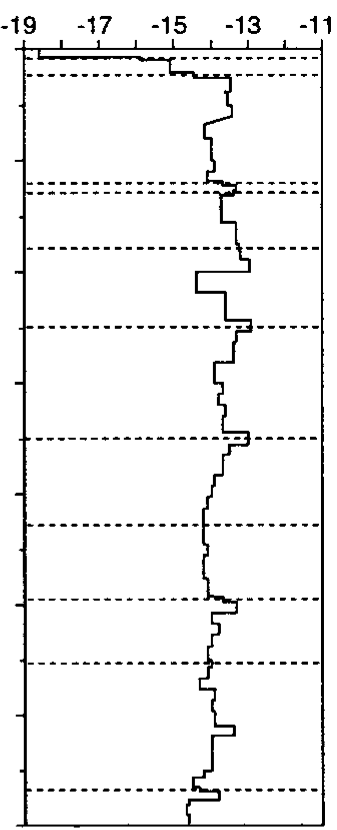

(e) $\mathrm{Na}+(\mu \mathrm{gL}-1)$

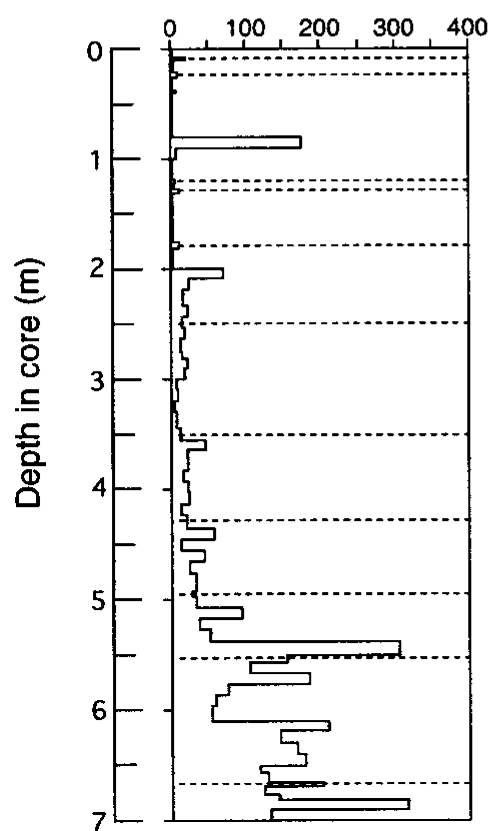

(f) $\mathrm{Cl}(\mu \mathrm{gL}-1)$

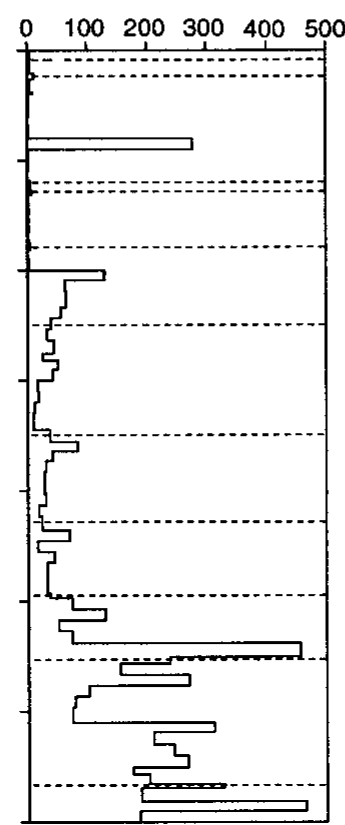

(g) $\mathrm{SO}_{4} 2-(\mu \mathrm{gL}-1)$

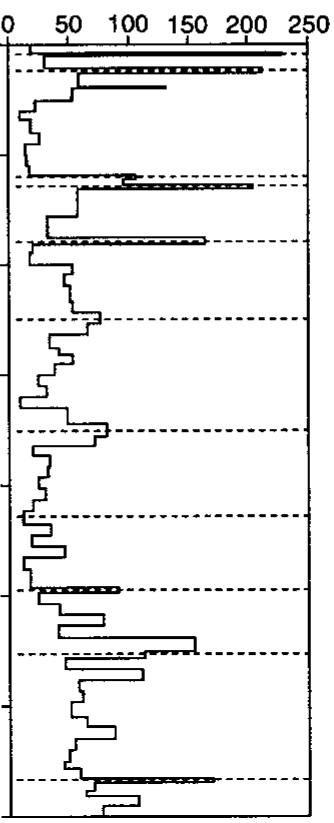

(h) $\mathrm{NO}_{3}^{-}(\mu \mathrm{gL}-1)$

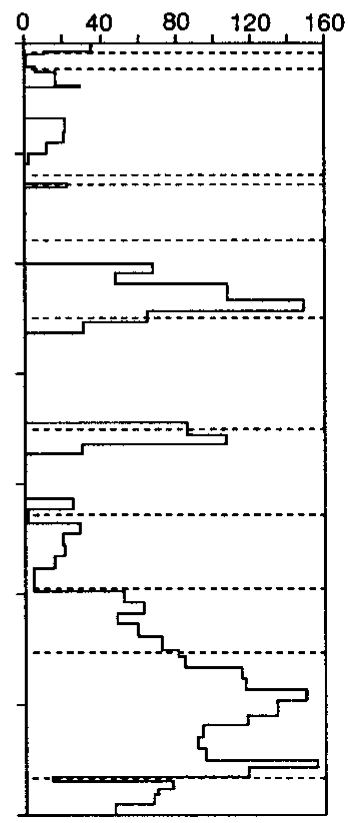

Fig. 2. Vertical profiles for ice-core samples at site A on Yala Glacier in 1994: (a) physical stratigraphy; (b) algal biomass; (c) microparticles (5-20 $\mu$ m in diameter); (d) oxygen isotope; $(e)$ sodium; $(f)$ chloride; $(g)$ sulfate; $(h)$ nitrate. Number of dirty layers $(D L)$ and algal layers $(A L)$ are shown. Years of algal-layers formation were estimated based on numbers of algal layers. Dashed lines show positions of algal layers. 


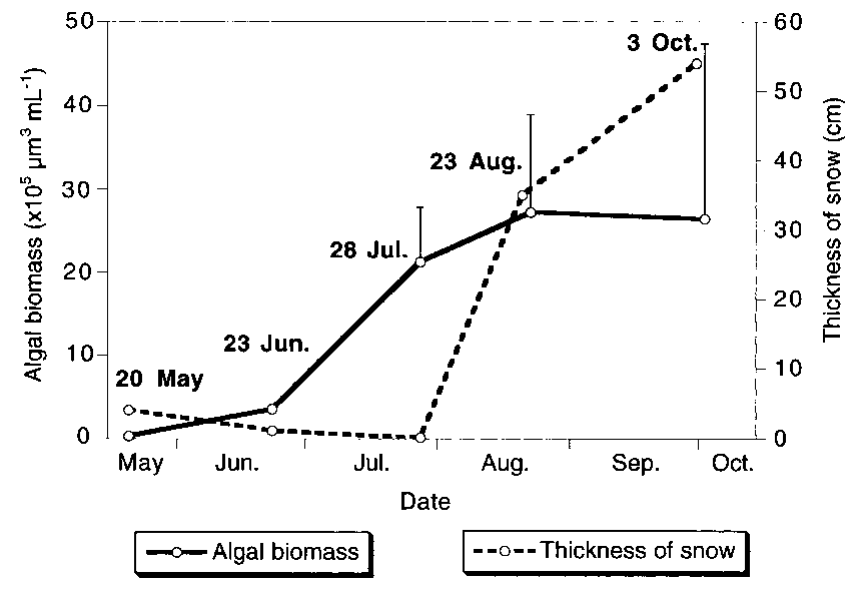

Fig. 3. Seasonal variation in algal biomass and thickness of snow on algal layers. Samples were collected at site A on 20 May, 23 June, 28 July, 23 August and 3 October 1996. Error bars indicate standard deviations.

tinued throughout the monsoon season, and during this period snow thickness on the layers increased. From May toJuly, there was virtually no snow on the algal layer. Snow rapidly increased after August, and by the beginning of October was $>50 \mathrm{~cm}$ high. Reduction in light intensity decreases exponentially with snow thickness (Richardson and Salisbury, 1977), and meltwater supply decreases with reduction in air temperature. Consequently algal growth in autumn is negligible. Algal layers in ice cores may thus be considered to have formed near the glacier surface during summer, as demonstrated in Figure 4, based on observations in 1996. In winter and spring, airborne dust particles containing spores and/or fragments of algae accumulate on the snow surface. In summer, the algae grow rapidly near the surface using meltwater, sunlight and nutrients present in the dust particles. In autumn when air temperature decreases and thick snow covers the algal layer, algal growth is smaller owing to decreased light intensity and meltwater, and the algal layer enters the glacier strata. Owing to seasonal variation, algal layers in ice cores may become boundary markers of annual layers useful for ice-core dating.

\section{Algal layers as boundary markers}

Figure $5 \mathrm{a}-\mathrm{c}$ show the stratigraphy of snow pits near site A on 21 August 1991, 14 August 1992 and 31 July 1994. The position

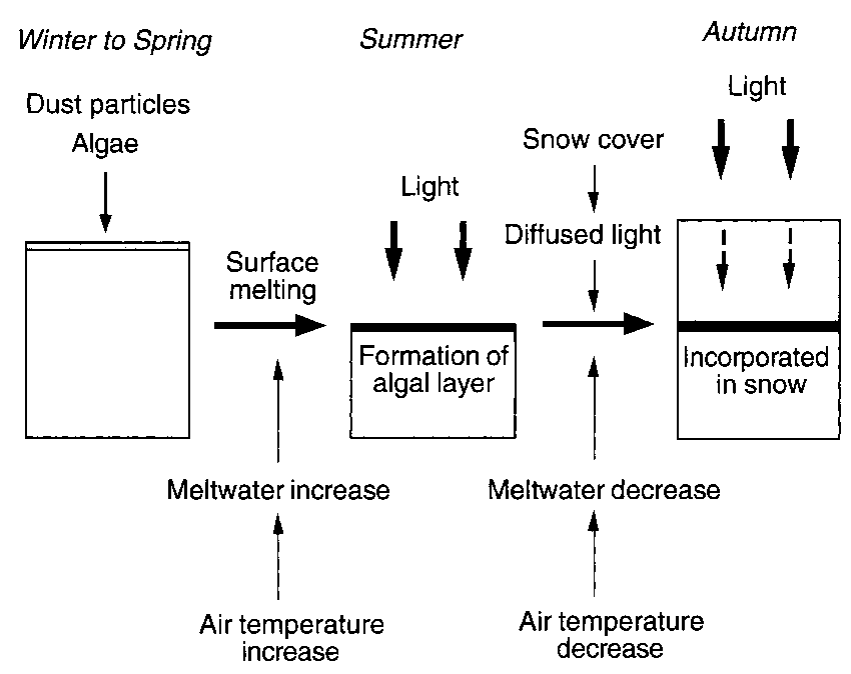

Fig. 4. Formation of algal layers based on observation in 1996.

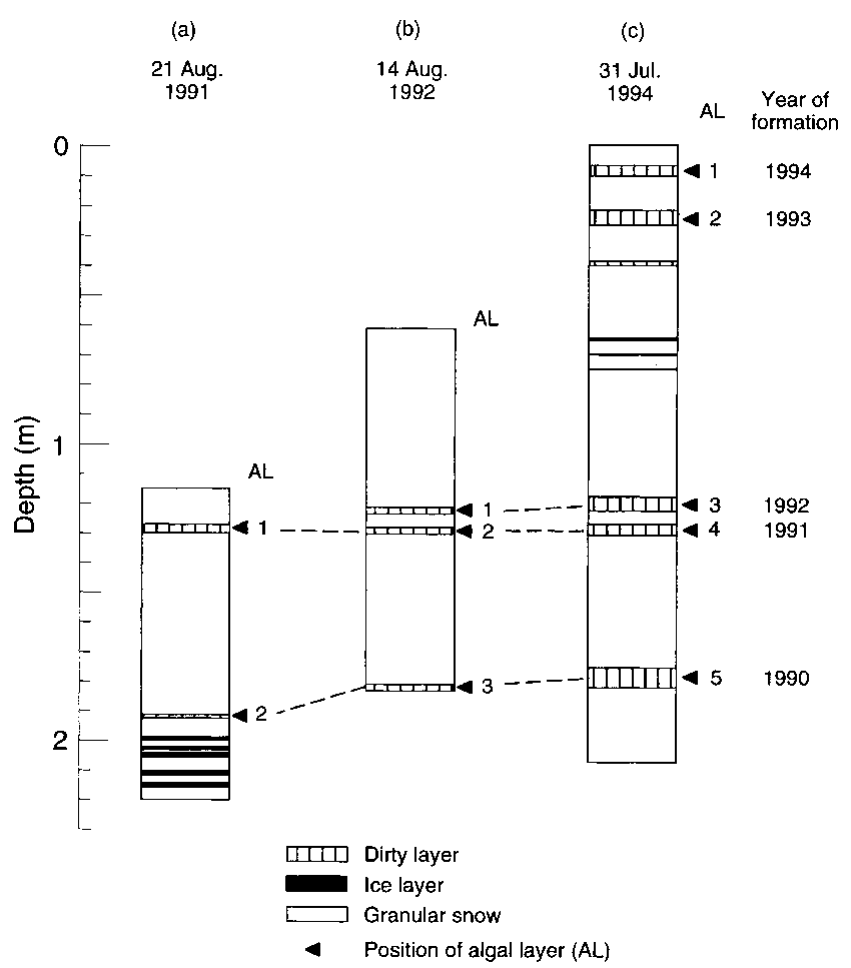

Fig. 5. Stratigraphy data for snow-pit walls on 21 August 1991 (a), 14 August 1992 (b) and 31 July 1994 (c). Number of algal layers $(A L)$ is shown, and years of algal-layers formation were estimated based on numbers of algal layers in the 1994 cores.

of the dirty layers and algal layers is shown and labeled by the year of formation which was estimated based on numbers of algal layers in the 1994 cores (Fig. 2a). One algal layer apparently formed annually from 1990 to 1994. In the 1992 pit, a new algal layer (ALl in Fig. 5b) was detected above the two algal layers in the 1991 pit (AL1 and AL2 in Fig. 5a). Two new algal layers (AL1 and AL2 in Fig. 5c) formed from 1992 to 1994 above the three algal layers ALl-3 in Figure 5b.

Figure 6 shows annual changes in algal biomass for
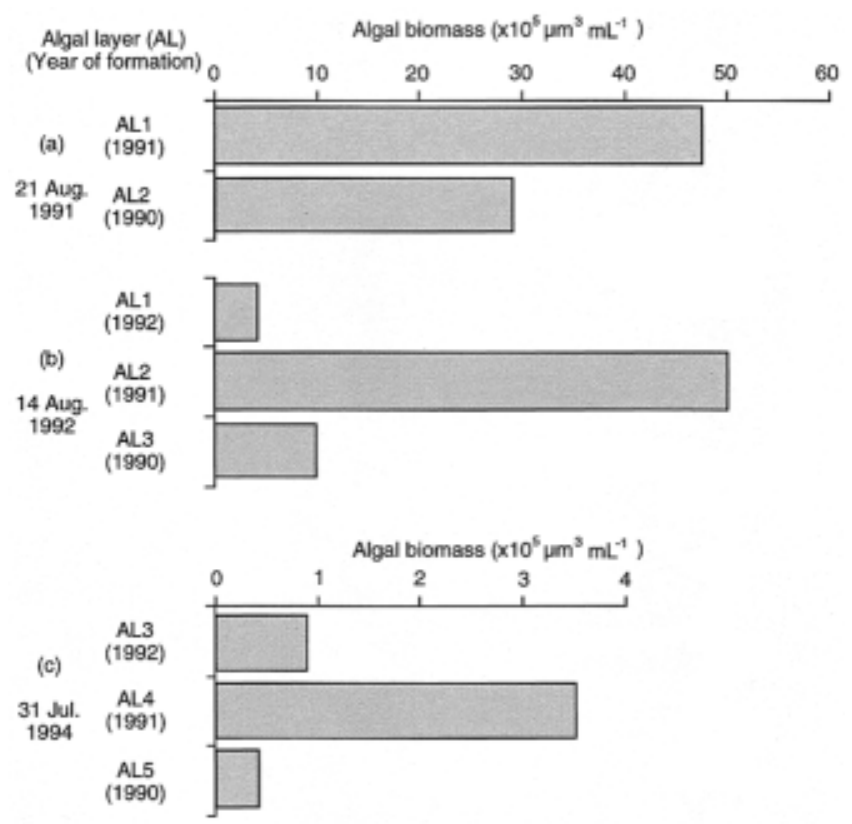

Fig. 6. Annual variation in algal biomass in algal layers (AL) of pit walls (1991, 1992 and 1994), as shown in Figure 5. Years of algal-layers formation were estimated based on numbers of algal layers in the 1994 cores. 
layers formed between 1990 and 1992. In all three pits, algal layer formation was found to have occurred in 1991 (AL1, AL2 and AL4 in Fig. 6a, b and c, respectively), and the layers contained much more algal biomass than other algal layers formed in 1990 and 1992. The three algal layers were thus considered to be the same layer that had formed in 1991. In summer 1991, snow on the algal habitat was thin and algal production was greater (Yoshimura and others, 1997). These findings support the dating of the algal layers. The present dating method using algal layers as boundary markers suggests the ice cores contained 11 years accumulation of snow (1984-94; Fig. 2a).

\section{Seasonal variation in dirty layers and microparticles}

The stratigraphy of ice cores indicated eight dirty layers (Fig. 2a). Though most of these (seven out of eight) coincided with the algal layers, some algal layers (four out of eleven) did not correspond to the dirty layers (Fig. 2a). In previous studies on Himalayan glaciers, dirty layers were used as boundary markers of annual layers. Miller and others (1965) and Steinegger and others (1993) determined, based on crevassewall observation, that two dirty layers are formed in pre- and post-monsoon dry seasons. Iida and others (1987) and Kohshima (1987a) suggested from pit observation at Yala Glacier that one distinct dirty layer containing much snow algae is formed annually on the ablation horizon of the pre-monsoon season and that another dirty layer containing no snow algae is occasionally formed on the ablation horizon of the post-monsoon season. The present results and clearly evident seasonal variation in algal growth in 1996 suggest most dirty layers form on the ablation horizon of the pre-monsoon season (Fig. 4). One dirty layer (DL3 in Fig. 2a) containing some algae may have formed on the ablation horizon in the post-monsoon season in 1992. Figure 2a suggests that on some ablation horizons with small amounts of particles and algae, visible dirty layers do not form. Figure 2c shows microparticle concentrations $(5-20 \mu \mathrm{m}$ in diameter). From the surface to a $2 \mathrm{~m}$ depth, microparticle peaks indicated the presence of algal and dirty layers. At $>2 \mathrm{~m}$, this presence was not clearly evident and the number of microparticle peaks exceeded those of algal and dirty layers, possibly due to relocation of microparticles by intense meltwater percolation and/or indefinite accumulation patterns. Dirty layers and microparticle concentrations may thus be unreliable means for ice-core dating.

\section{Seasonal variation in ${ }^{18} \mathrm{O}$}

Seasonal variation in isotopes in Himalayan precipitation differs from that in polar precipitation. Wushiki (1977) showed deuterium to be present at high concentration in pre-monsoon precipitation in Khumbu region, east Nepal, but only slightly present at mid-monsoon. He attributed the high concentration to the direct transport of water vapor from the Indian Ocean to the Himalaya without much rainfall on the way. Oxygen isotope $\left(\delta^{18} \mathrm{O}\right)$ values for precipitation in Kyangjing village (3920 ma.s.l.; Fig. la) in the Langtang region show essentially the same seasonal variation (K. Seko and T. Kadota, unpublished information). Seasonal variation in $\delta^{18} \mathrm{O}$ in ice cores (Fig. 2d) near the surface could not be clearly determined. The lowest value for $\delta^{18} \mathrm{O}(<-18$ per mil) was detected near the surface (monsoon snow of 1994), but no distinct peak between ALl and AL2 (pre-monsoon accumulation of 1994) was found. This unclear seasonal variation may have been due to meltwater percolation. At greater glacier depth $(>1 \mathrm{~m})$, seven distinct $\delta^{18} \mathrm{O}$ peaks were noted, six of which roughly corresponded to the peaks in the algal biomass. Thus, although seasonal variation in $\delta^{18} \mathrm{O}$ is roughly constant in ice cores, it may become considerably attenuated as a result of large-scale melting.

\section{Seasonal variation in major-ion concentrations}

Sodium and chloride concentrations (Fig. 2e and f) were basically the same. At $2 \mathrm{~m}$ depth, small concentrations peaks appeared, coinciding with algal layers (ablation horizon in pre-monsoon season, 1990-94), and a large concentrations peak corresponded to a granular snow layer $(80-90 \mathrm{~cm}$ deep) formed between the pre-monsoon seasons of 1992 and 1993. In the Himalaya, sodium and chloride concentrations are believed to be influenced by monsoonal vapor transport from the Indian Ocean (Wake and others, 1990), so these concentrations peaks may have been due to monsoonal snow. But seasonal variation was unclear, and more than one peak sometimes appeared in one year. The ion concentrations increased from a $2 \mathrm{~m}$ to a $7 \mathrm{~m}$ depth, and their relation to algal layers was unclear, possibly because ions were taken away by meltwater and concentrated at ice layers.

Sulfate concentration was higher in dirty layers and algal layers except for AL8 (Fig. 2g). At $>2$ m depth, concentrations peaks increased, making seasonal variation difficult to detect. Percolation of meltwater may have been the reason for this. Wake and others (1990) and Wake and Mayewski (1993) suggest that sulfate in central Asia may have derived from desert mineral aerosol, anthropogenic emission from the Indian subcontinent and the like. Sulfate peaks in this study corresponded to dirty layers, so the source of sulfate may have been mineral particles that had accumulated in dry seasons. Nitrate concentration showed no definite trend (Fig. 2h).

\section{CONGLUSIONS}

Algal layers may serve well as boundary markers of annual layers in ice-core dating, but it is difficult to distinguish the boundaries of annual layers from dirty layers, microparticles, $\delta^{18} \mathrm{O}$ and major-ion concentrations,. This is especially true at depths of $>2 \mathrm{~m}$, possibly because of meltwater percolation. Algal-layer usefulness may be explained in part based on algal size, ranging from 5 to $20 \mu \mathrm{m}$, which makes it difficult for algae to be washed away by meltwater. Seasonal variation is also a factor for usefulness in dating. Algal layers form in summer and become incorporated into the glacial strata in autumn. Some microparticles are almost the same size $(5-20 \mu \mathrm{m})$ as algae but provide no indication of annual layers, perhaps because the rate of particle accumulation changes owing to meteorological conditions, causing microparticles to have an indefinite seasonal variation. $\delta^{18} \mathrm{O}$ showed relatively clear seasonal variation, but peak values in ice cores fluctuated, owing to meltwater percolation.

Snow algae may be useful for ice-core dating but there are limitations. The detection and identification of algae in deeper parts of ice cores can be problematic, and in the present study were difficult to carry out below $5 \mathrm{~m}$ due perhaps to autolysis or bacterial decomposition. For these purposes, algal traces should be measured.

In general, in alpine glaciers in mid-latitudinal regions, one of the most important and difficult problems is to mini- 
mize the influence of meltwater percolation (Wagenbach, 1989). Snow algae may provide a solution to this problem, not only for Yala Glacier, but also for other glaciers throughout the world.

\section{AGKNOWLEDGEMENTS}

The authors express sincere appreciation to the Department of Hydrology and Meteorology, Ministry of Water Resources, Nepal, for valuable support. The Sherpa people and Langtang village are acknowledged for their kind assistance in Nepal. Thanks are due to M. Igarashi of the National Institute of Polar Research for ion-concentration determination and microparticles analysis and to T. Kadota of Nagoya University for information for oxygen isotope data in Kyangjing. R. M. Koerner and C. Tobin are thanked for providing critical reviews. This study was supported by the Ministry of Education, Science, Sports and Culture of Japan under grant Nos. 06041051 and 09490018.

\section{REFERENGES}

Abyzov, S. S. and 6 others. 1995. Glaciological and microbiological description of the ice core in central Antarctica. Acad. Sci. U.S.S.R. Biol. Bull., $22(5), 441-446$.

Bourgeois, J. C. 1990. A modern pollen spectrum from Dye 3, south Greenland ice sheet. F. Glaciol., 36(124), 340-342.

Fredskild, B. and P. Wagner. 1974. Pollen and fragments of plant tissue in core samples from the Greenland ice cap. Boreas, 3(3), 105-108.

Gerdel, R.W. and F. Drouet. 1958. The cryoconite of the Thule area. SIPRE Res. Rep. 50.

Iida, H., Y. Endo, S. Kohshima, H. Motoyama and O. Watanabe. 1987. Characteristics of snow cover and formation process of dirt layer in the accumulation area of Yala Glacier, Langtang Himal, Nepal. Bull. Glacier Res. 5, 55-62.

Karl, D. M., D. F. Bird, K. Bjorkman, T. Houlihan, R. Shackelford and L. Tupas. 1999. Microorganisms in the accreted ice of Lake Vostok, Antarctica. Science, 286(5447), 2144-2147.

Koerner, R. M., J. C. Bourgeois and D. A. Fisher. 1988. Pollen analysis and discussion of time-scales in Canadian ice cores. Ann. Glaciol., 10, 85-91.

Kohshima, S. 1984a. Living micro-plants in the dirt layer dust of Yala Glacier, Nepal Himalaya. Bull. Glacier Res. 2, 91-97.

Kohshima, S. 1984b. A novel cold-tolerant insect found in a Himalayan glacier. Nature, 310(5974), 225-227.

Kohshima, S. 1987a. Formation of dirt layers and surface dust by micro-plant growth in Yala (Dakpatsen) Glacier, Nepal Himalayas. Bull. Glacier Res. 5, 63-68.

Kohshima, S. 1987b. Glacial biology and biotic communities. In Kawano, S., J. H. Connell and T. Hidaka, eds. Evolution and coadaptation in biotic communities. Kyoto, Kyoto University. Faculty of Science, 77-92.
Kohshima, S. 1989. Glaciological importance of microorganisms in the surface mud-like materials and dirt layer particles of the Chongce Ice Cap and Gozha Glacier, West Kunlun Mountains, China. Bull. Glacier Res. 7, 59-65.

Kol, E. 1942. The snow and ice algae of Alaska. Smithson. Misc. Collect., $101(16)$.

Kol, E. 1969. The red snow of Greenland. II. Acta Bot. Acad. Sci. Hung., 15(3-4), 281-289.

Kol, E. and S. Eurola. 1974. Red snow algae from Spitsbergen. Astarte, 7(2), $61-66$.

Kol, E. and E. A. Flint. 1968. Algae in green ice from the Balleny Islands, Antarctica. N.Z. J. Bot., 6(3), 249-261.

Kol, E. and J. A. Peterson. 1976. Cryobiology. In Hope, G. S., J. A. Peterson, U. Radok and I. Allison, eds. The equatorial glaciers of New Guinea: results of the 1971- 1973 Australian Universities' expeditions to Irian Faya. Rotterdam, A. A. Balkema, 81-91.

Ling, H. U. and R. D. Seppelt. 1993. Snow algae of the Windmill Islands, continental Antarctica. 2: Chloromonas Rubroleosa sp. nov. (Volvocales, Chlorophyta), an alga of red snow. Eur. F. Phycol., 28(2), 77-84.

McAndrews, J. H. 1984. Pollen analysis of the 1973 ice core from Devon Island glacier, Canada. Quat. Res., 22(1), 68-76.

Miller, M. M., J. S. Leventhal and W. F. Libby. 1965. Tritium in Mt. Everest ice - annual glacier accumulation and climatology at great equatorial altitudes. 7. Geophys. Res., 70(16), 3885-3888.

Priscu, J. C. and 11 others. 1999. Geomicrobiology of subglacial ice above Lake Vostok, Antarctica. Science, 286(5447), 2141-2144.

Richardson, S. G. and F. B. Salisbury. 1977. Plant responses to the light penetrating snow, Ecology, 58, 1152-1158.

Steinegger, U., L. N. Braun, G. Kappenberger and G. Tartari. 1993. Assessment of annual snow accumulation over the past 10 years at high elevations in the Langtang region. International Association of Hydrological Sciences Publication 218 (Symposium at Kathmandu 1992 - Snow and Glacier Hydrology), 155-165.

Wagenbach, D. 1989. Environmental records in alpine glaciers. In Oeschger, H. and C. C. Langway, Jr, eds. The environmental record in glaciers and ice sheets. Chichester, etc., John Wiley and Sons, 69-83.

Wake, C. P. and P. A. Mayewski. 1993. The spatial variation of Asian dust and marine aerosol contributions to glaciochemical signals in central Asia. International Association of Hydrological Sciences Publication 218 (Symposium at Kathmandu 1992 - Snow and Glacier Hydrology), 385-402.

Wake, C. P., P. A. Mayewski and M. J. Spencer. 1990. A review of central Asian glaciochemical data. Ann. Glaciol., 14, 301-306.

Wharton, R. A., Jr, W. C. Vinyard, B. C. Parker, G. M. Simmons, Jr and K. G. Seaburg. 1981. Algae in cryoconite holes on Canada Glacier in southern Victoria Land, Antarctica. Phycologia, 20(2), 208-211.

Willerslev, E., A. J. Hansen, B. Christensen, J. P. Steffensen and P. Arctander. 1999. Diversity of Holocene life forms in fossil glacier ice. Proc. Natl. Acad. Sci. U.S.A., 96 (14), 8017-8021.

Wushiki, H. 1977. Deuterium content in the Himalayan precipitation at Khumbu District, observed in 1974/1975. Seppyo, 7. Jpn. Soc. Snow Ice, Special Issue 39, Part II, 50-56.

Yoshimura, Y., S. Kohshima and S. Ohtani. 1997. A community of snow algae on a Himalayan glacier: change of algal biomass and community structure with altitude. Arct. Alp. Res., 29(1), 126-137. 